

\title{
Intersexuality in Crustaceans: Genetic, Individual and Population level effects
}

\author{
Alex T. Ford, Christine Sambles, Peter Kille
}

\section{To cite this version:}

Alex T. Ford, Christine Sambles, Peter Kille. Intersexuality in Crustaceans: Genetic, Individual and Population level effects. Marine Environmental Research, 2008, 66 (1), pp.146. 10.1016/j.marenvres.2008.02.067 . hal-00501959

\section{HAL Id: hal-00501959 \\ https://hal.science/hal-00501959}

Submitted on 13 Jul 2010

HAL is a multi-disciplinary open access archive for the deposit and dissemination of scientific research documents, whether they are published or not. The documents may come from teaching and research institutions in France or abroad, or from public or private research centers.
L'archive ouverte pluridisciplinaire HAL, est destinée au dépôt et à la diffusion de documents scientifiques de niveau recherche, publiés ou non, émanant des établissements d'enseignement et de recherche français ou étrangers, des laboratoires publics ou privés. 


\section{Accepted Manuscript}

Intersexuality in Crustaceans: Genetic, Individual and Population level effects

Alex T. Ford, Christine Sambles, Peter Kille

PII:

S0141-1136(08)00065-2

DOI:

10.1016/j.marenvres.2008.02.067

Reference:

MERE 3217

To appear in:

Marine Environmental Research

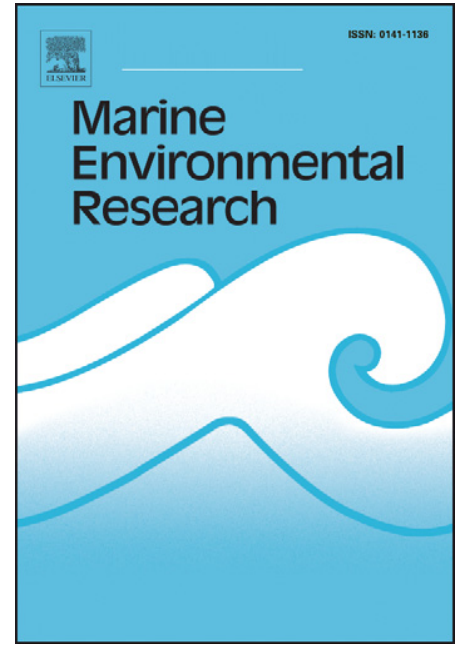

Please cite this article as: Ford, A.T., Sambles, C., Kille, P., Intersexuality in Crustaceans: Genetic, Individual and Population level effects, Marine Environmental Research (2008), doi: 10.1016/j.marenvres.2008.02.067

This is a PDF file of an unedited manuscript that has been accepted for publication. As a service to our customers we are providing this early version of the manuscript. The manuscript will undergo copyediting, typesetting, and review of the resulting proof before it is published in its final form. Please note that during the production process errors may be discovered which could affect the content, and all legal disclaimers that apply to the journal pertain. 


\title{
Intersexuality in Crustaceans: Genetic, Individual and Population level effects
}

\author{
Alex T. Ford ${ }^{\text {a,* }}$, Christine Sambles ${ }^{\text {b }}$, Peter Kille ${ }^{\text {b }}$ \\ ${ }^{a}$ Environmental Research Institute, North Highland College, UHI Millennium Institute, Castle Street, Thurso, \\ Caithness, Scotland, UK, KW14 7JD \\ ${ }^{b}$ School of Biosciences, University of Wales Cardiff, Main Building, Museum Avenue, Cardiff, Wales, UK, CF10 $3 T L$
}

\begin{abstract}
Scientists investigating toxicants such as endocrine disrupting chemicals (EDCs) at the cellular at the sub-cellular level are often faced with criticisms as to how these effects can be extrapolated to the level of individuals and their populations. This report aims to provide an overview of the studies undertaken on crustacean model, Echinogammarus marinus LEACH (AMPHIPODA), and intersex phenotypes, at the individual and population levels, and provide additional emergent data at the genomic level. These, normal and intersex, males and females have been investigated by cross-hybridisation microarray analysis and specific sexually dimorphic genes and corresponding properties identified between each sexual phenotype. The morphology, physiology and histology of these intersexes have been investigated in detail and a number of reproductive costs have been identified including reduced fecundity and fertility. These costs have been incorporated into a population model and simulated over a ten-year period to ascertain how different levels of intersexuality affect the stability of populations. Based on the information
\end{abstract}




\section{ACCEPTED MANUSCRIPT}

gained through study of intersex models (with known endocrine dysfunction) together with the substantial quantity of historical data relating to effects of chemicals on amphipod fecundity, growth and mortality, the development of appropriate biomarkers is nearer to being assessed from the level of genes to that of the population.

Keywords: Endocrine disruption; Invertebrates; Biomarkers; Microarray; Population modelling; Intersexuality

"Corresponding author: Tel.: +44-1847-889593; fax: +44-1847-890014.

E-mail address: alex.ford@ thurso.uhi.ac.uk (A. Ford)

Many of the studies of endocrine disruption (ED) have arisen through the discovery of sexual abnormalities (including intersexuality) in wildlife (Colburn et al., 1996). One of the problems faced by toxicologists investigating $\mathrm{ED}$ in invertebrates is that the genetics and endocrinology are not as fully understood as those in vertebrate models (Defur et al., 1999). Consequently, the search for and pace of development of suitable biomarkers for laboratory and field monitoring has been relatively slow. Invertebrates do however provide some advantages over vertebrates due to their simple and inexpensive methods of culture, as well as fast generation times making them more amenable to population studies.

Male and female amphipods can be distinguished from each other by the presence of genital papillae (males) and brood plates/oostegites (females). Intersex specimens can be observed displaying both genital papillae and brood plates. Intersexuality in the amphipod E. marinus exists as two phenotypes, namely, intersex male and intersex female (for descriptions see Ford et al., 2004a). These abnormal specimens provide a unique opportunity to study varying types of 


\section{ACCEPTED MANUSCRIPT}

endocrine dysfunction and develop endocrine specific biomarkers at several levels of biological organisation. Ford et al. (2004a) observed higher proportions of intersex E. marinus at sites associated with pollution when compared to reference sites. These intersexes have subsequently been reported to be caused by feminising microsporidian parasites possibly enhanced through polluted conditions (Ford et al., 2006). Recently, intersex has been demonstrated to be induced chemically in Crustacea by juvenile hormone mimics (Olmstead and LeBlanc, 2007). Intersexuality can also be induced in amphipods by the ablation or implantation of androgenic glands, from/into males and females, respectively (Charniaux-Cotton, 1958).

A number of costs associated with intersexuality at the individual level have been reported in E. marinus including lower fecundity and fertility; and delayed maturation (Ford et al., 2004b; Table 1). Morphologically, histologically and behaviourally intersex specimens separate into two phenotypes, intersex male and intersex female. When comparing the morphology of normal male E. marinus from clean and polluted sites with the standard morphology of an intersex male, discriminant analysis revealed normal males from an industrially polluted site in Scotland had a morphology most similar to that of intersex males (Ford et al., 2004a). Considering feminising parasites are infrequently found in normal male E. marinus, the authors suggested that subtle endocrine disruption maybe occurring, possibly relating to effects associated with the androgenic gland.

Martins et al. (2002) modelled populations of E. marinus in response to environmental parameters (salinity, temperature) based upon a population with no intersexes and equal numbers of males and females (1:1). In view of the costs associated with intersexuality, this model was subsequently adapted by to include proportions of intersex females and the reproductive costs associated with intersexuality (Ford et al., 2007). Simulations were undertaken with varying sex ratios, fecundity, mortality and intersex proportions and revealed that the inclusion of intersexes 


\section{ACCEPTED MANUSCRIPT}

can have dramatic effects on the population. (for details please refer to Ford et al., 2007; summarised in Table 1).

To date, genomics resources available for Crustacea species encompass a complete genome sequence for the water flea Daphnia pulex (http://wfleabase.org/) together with limited EST (Expressed Sequence Tag) studies for a small number of other crustaceans. Gammarus pulex cDNA libraries were generated representing a range of developmental stages and phases of the moult-cycle for both sexes together with sex-specific subtractive suppression hybridisation libraries. These libraries have been used to generate 9600 full-length directional ESTs, together with 3,840 EST fragments from a male enriched SSH library.

We used these ESTs to generate a glass-slide microarray that demonstrated consistent hybridisation (83\% significant signal above background) to total RNA from E. marinus. Normal and intersex male and female E. marinus were sampled from Inverkeithing Bay (Scotland). Whole organisms $(n=24)$ were used to generate total RNA which was subsequently used as a template for cDNA synthesis in the presence of aminoallyl dUTP and subsequently coupled to monofunctional NHS-ester of Cy3. Samples were then hybridised against a common reference oligonucleotide labelled with Cy5. Hybridisations were imaged and spot intensities quantified using image analysis software Spot (http://spot.cmis.csiro.au/spot/index.php). Results were subsequently imported into GeneSpring GX (http://www.chem.agilent.com/) for normalisation and statistical analysis (see Figure 1 for details). Analysis of variance of all samples revealed 582 genes which differed significantly between all groups (normal and intersex males and females). Subsequent PCA analysis of the transcript profile of these differentially expressed genes within the individual specimens showed a clear separation between normal males and females and intersex groups separated from their normal counterparts (Fig. 1). Interestingly, the clustering of intersex males and females together runs contrary to their phenotypic variation, suggesting a relatively few genes may influence large changes in secondary sexually dimorphic characteristics. 


\section{ACCEPTED MANUSCRIPT}

Preliminary analysis of microarray data has revealed a vast array of potential genetic biomarkers for assessing (de)-feminisation and/or (de)-masculinisation in Crustacea. The role of individual genes and their potential for biomarkers of EDCs and toxicants is currently under further investigation. E. marinus provides a unique species for studying intersexuality and currently remains one of the only intersex models to have been studied at the genome level up to that of the population.

\section{References}

Barbeau, M. A., and Grecian, L. A. (2003). Crustaceana, 76, 665-679.

Colborn, T., Peterson, M.J., and Dumanoski, D. (1996). Our stolen future, Little, Brown and Co., Boston.

Defur, P. L., Crane, M., Ingersoll, C., and Tattersfield, L. (1999) Endocrine Disruption in Invertebrates: Endocrinology, Testing and Assessment, SETAC Technical Publication, Pensacola, FL.

Ford A.T., Fernandes T.F., Rider S.A., Read P.A., Robinson C.D., and Davies I.M. (2004a). Marine Environmental Research, 58, 169-173.

Ford A.T., Fernandes T.F., Read P.A., Robinson C.D., and Davies I.M. (2004b). Marine Biology, $145,951-957$.

Ford A.T., Roders-Gray T.P., Davies I.M., Dunn A., Read P.A., Smith J.E., et al. (2005). Marine Biology, 148, 913-918.

Ford A.T., Fernandes T.F., Read P.A., Robinson C.D., and Davies I.M. (2006). Marine Pollution Bulletin, 53, 100-106.

Ford A.T., Martins, I., and Fernandes, T.F. (2007). Science of the Total Environment, 374, 102111.

Martins, I., Maranhão, P., and Marques, J.C. (2002). Ecological Modelling, 153, 247-260. 
Olmstead, A.W., and Leblanc, G. A. (2007). International Journal of Biological Sciences, 3, 77-84. 
Figure caption

Fig. 1: Principal component analysis of individual transcript profiles of normal and intersex males and female E. marinus ( $ぇ$ male; $\widehat{\jmath} \mathbf{i}$ intersex male; $\bigcirc$ female; $\subsetneq \mathbf{i}$ intersex female). Array data was normalised by dividing by the common reference channel followed by normalising each gene expression by its average over all samples together with normalising slide distribution to the $50^{\text {th }}$ percentile. Genes that showed $>2$ change and statistically significant differences between 'Sex' groups (normal and intersex males and females) were analyzed using a non-parametric test (Kruskal-Wallis test) p-value cut-off 0.05 yielding 582 genes. The expression of these genes was then used in a PCA analysis of the individual specimen transcript profiles. [* outlier]. 
Figure 1

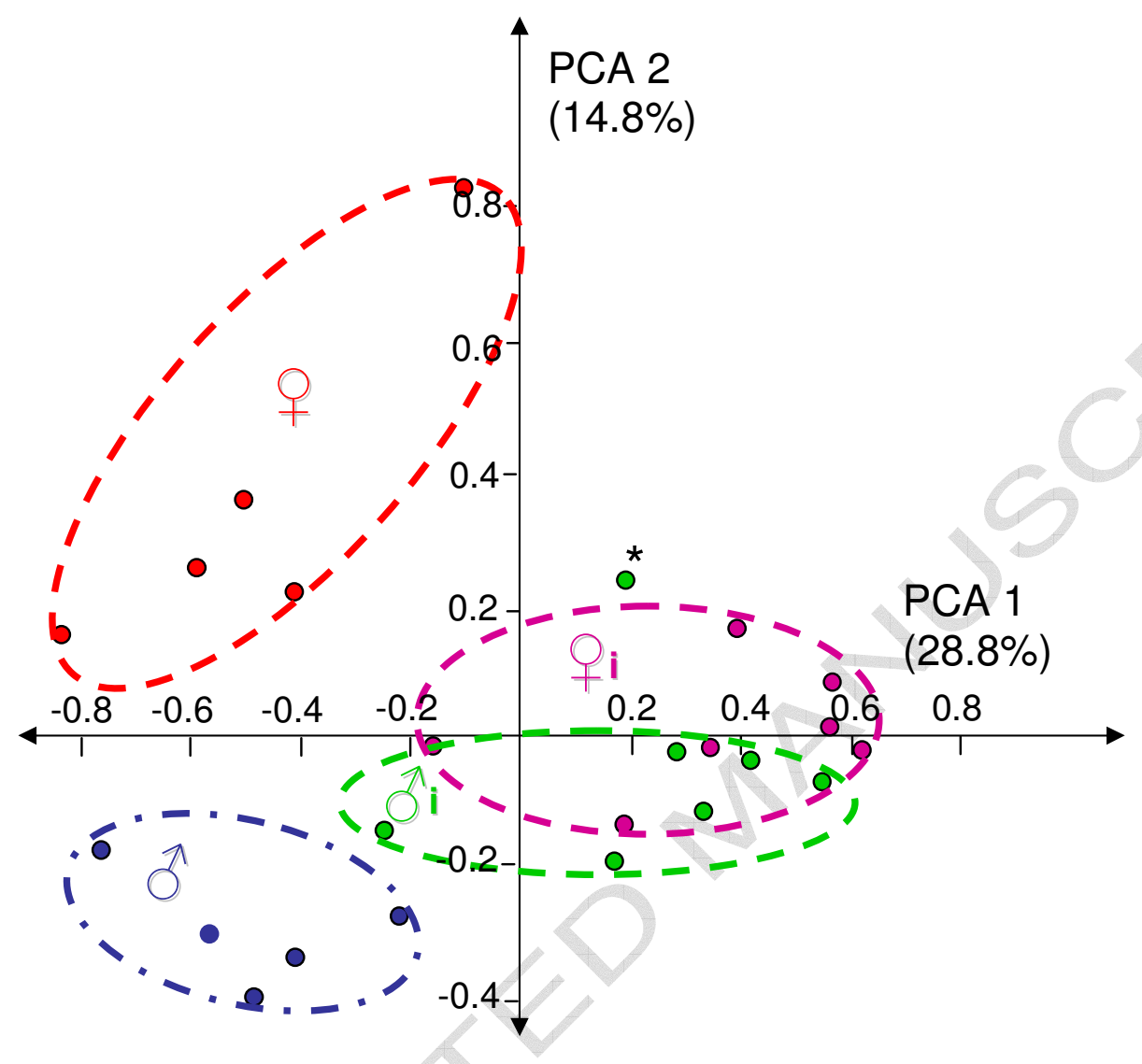


Table 1.

Overview of published data on normal and intersex Echinogammarus marinus investigated at three levels of biological organisation.

\begin{tabular}{|c|c|}
\hline $\begin{array}{c}\text { Organisation } \\
\text { level }\end{array}$ & Biomarkers and/or Bioindicators \\
\hline Genetic to cellular & $\begin{array}{l}\text { - Microarrays have differentiated }>580 \text { genes between normal and intersex } \\
\text { specimens, with } 512 \text { and } 593 \text { genes significantly differed between normal and } \\
\text { intersex populations for females and males groups, respectively (this study). } \\
\text { - Identification of specific gene function for quantitative and qualitative biomarker } \\
\text { development are currently underway. Preliminary characterization of these libraries } \\
\text { has yielded, amongst other novel sequences, a gammarid vitellogenin cDNA, which } \\
\text { has successfully been used as a female sex specific marker, and a putative nuclear } \\
\text { receptor similar to Drosophila melanogaster HR3 which is a moult-regulating } \\
\text { transcription factor (Sambles et al., unpublished data). These ESTs have been } \\
\text { sequenced and clustered to generate } 3917 \text { gene objects which are included with their } \\
\text { homology annotation in a Crustacea genome resource curated by Professor Mark } \\
\text { Blaxter } \\
\text { (http://www.nematodes.org/NeglectedGenomes/ARTHROPODA/Crustacea.html). } \\
\text { - Reduced androgenic gland activity in intersex (male and female) versus normal } \\
\text { males quantified by MALDI-TOFF spectrometry (Ford et al., 2005). }\end{array}$ \\
\hline In & $\begin{array}{l}\text { - External morphometric differences between normal and intersex specimens (Ford } \\
\text { et al., 2004a). Intersex males externally show the development of 'female' immature } \\
\text { brood plates, whilst intersex females externally display 'male' genital papillae. } \\
\text { - Internal differences in gonodal structure between normal and intersex specimens } \\
\text { (Ford et al. 2005). Intersex male E. marinus internally display oviducts and vas } \\
\text { defera have been observed in intersex females (Ford et al., 2005).Histological } \\
\text { analysis has revealed both the inclusion of ovarian and testicular tissues in some } \\
\text { intersex amphipods. } \\
\text { - Behaviourally intersex females and intersex males act as do normal females and } \\
\text { males, respectively (Ford et al., 2007). } \\
\text { - Normal male E. marinus at polluted sites display close morphology to intersex } \\
\text { specimens at polluted sites. Suspected de-masculinisation and anti-androgenic } \\
\text { activity (Ford et al., 2004a). } \\
\text { - Reduced fecundity and fertility in female intersexes. Intersex female E. marinus } \\
\text { produce } 20 \% \text { fewer eggs than normal females. } 10 \% \text { fewer eggs from intersex } \\
\text { females develop fully as embryos compared to normal females (Ford et al., 2004b). } \\
\text { - Increased size and delayed maturation in intersexes. Intersexes grow } ~ 10 \% \text { larger } \\
\text { than normal specimens (Ford et al., 2004b). } \\
\text { - Reduced pairing success in intersex females. Possible pheromone dysfunction } \\
\text { (Ford et al., 2004b; and papers within). } \\
\text { - Reduced fertility in intersex male Corophium volutator (Barbeau and Grecian, } \\
\text { 2003). }\end{array}$ \\
\hline Popu & $\begin{array}{l}\text { - Simulated population extinction within approximately } 6 \text { years if } 5 \% \text { of normal } \\
\text { females are replaced by intersex females (Ford et al., 2007). } \\
\text { - Rapid population growth if normal males are replaced by intersex females. This } \\
\text { population growth however can be negated by } \sim 10 \% \text { reductions in normal female } \\
\text { fecundity (Ford et al., 2007). }\end{array}$ \\
\hline
\end{tabular}

